\title{
An Air Quality Assessment of Haldwani City of Uttarakhand
}

\author{
Muchkund Pant, Mr. Awadhesh Chandramauli
}

\begin{abstract}
Air is very important for the survival of human beings. But the rapid industrialisation, increase in no of vehicles, construction work, deforestation increasing level of pollutants in air it degrade air quality. The present study is about the air quality assessment of Haldwani city of Uttarakhand observing PM10,SPM, $\mathrm{SO}_{2}$ and $\mathrm{NO}_{2}$ data of year 2018. The PM10 and SPM value is more then permissible limit but the value of $\mathrm{SO}_{2}$ and $\mathrm{NO}_{2}$ within the limit.
\end{abstract}

Keyword - Air Quality, Haldwani, $\mathrm{CPCB}, \mathrm{NO}_{\mathrm{x}}$

\section{INTRODUCTION}

Haldwani is located in the state of Uttarakhand at $29.22^{\circ} \mathrm{N}$ latitude $79.52^{\circ} \mathrm{E}$ longitude in the Nainital district on the right bank of the Gaula River and being situated in the immediate foothills of Kumaon Himalayas. Haldwani is the second most populous city, the largest commercial market in the Indian state Uttarakhand. The air quality is generally described as a combination of the physical and chemical characteristics that make air a healthful resource for human, animal and plants. Air pollutants can directly affect flora and fauna. In urban areas vehicular emission is main reasons of air quality problems. SOx, NOx, COx are produced by vehicles. SPM,PM10,PM2.5 contaminants produced by construction dust and other human made activities. Industrial pollutant also affect the quality of air. The polluted air can cause a serious health problems.

\section{METHODOLOGY}

\section{Study sites}

The study site is air quality measuring instrument present in government hospital Haldwani.

\section{A. Permissible limits}

According to Central Pollution Control Board (CPCB) the current National Ambient Air Quality Standards were notified on 18 November 2009 are follows

Manuscript revised June 7, 2019 and published on July 10, 2019 Muchkund Pant, M.tech Environmental Engineering Student, Department of Civil Engineering, Uttaranchal University Dehradun.

Mr. Awadhesh Chandramauli, Assistant Professor Department of Civil Engineering,. Uttaranchal University Dehradun.
Table 1: National Ambient Air Quality Standards by CPCB

\begin{tabular}{ccc}
\hline Pollutant & Annual & 24 hours \\
\hline PM10 & 60 & 100 \\
$\mathrm{SPM}$ & 40 & 60 \\
$\mathrm{NO}_{2}$ & 40 & 80 \\
$\mathrm{SO}_{2}$ & 50 & 80 \\
\hline
\end{tabular}

\section{OBSERVATION}

12 month data of 2018 different air quality parameters follows:

Table II: Observation table of different month of 2018

\begin{tabular}{|c|c|c|c|c|}
\hline & $\operatorname{PM} 10\left(\mu \mathrm{g} / \mathrm{m}^{3}\right)$ & $\operatorname{SPM}\left(\mu \mathrm{g} / \mathrm{m}^{3}\right)$ & $\mathrm{SO}_{2}\left(\mu \mathrm{g} / \mathrm{m}^{3}\right)$ & $\mathrm{NO}_{2}\left(\mu \mathrm{g} / \mathrm{m}^{3}\right)$ \\
\hline Jan & 129.89 & 206.95 & 11.66 & 23.79 \\
\hline $\mathrm{Feb}$ & 130.37 & 213.22 & 11.69 & 23.67 \\
\hline Mar & 132.27 & 219.3 & 11.73 & 23.7 \\
\hline April & 131.22 & 216.6 & 11.69 & 23.74 \\
\hline May & 128.48 & 212.86 & 11.9 & 23.36 \\
\hline June & 128.14 & 208.83 & 11.61 & 23.3 \\
\hline July & 125.28 & 196.92 & 11.33 & 23.01 \\
\hline Aug & 119.34 & 188.63 & 11.35 & 22.42 \\
\hline Sept. & 124.71 & 191.15 & 11.64 & 22.85 \\
\hline Oct. & 123.8 & 189.91 & 11.03 & 21.42 \\
\hline Nov. & 119.23 & 186.08 & 12.3 & 22.06 \\
\hline Dec. & 118.37 & 185.37 & 8.65 & 21.99 \\
\hline
\end{tabular}




$$
\text { E-ISSN: 2321-9637 }
$$

Available online at www.ijrat.org

\section{RESULTS}

We can draw following results from the above observation table:

\section{A. PM10}

PM10 value lie between $118.37 \mu \mathrm{g} / \mathrm{m}^{3}$ to $132.27 \mu \mathrm{g} / \mathrm{m}^{3}$. The highest value observed is $132.27 \mu \mathrm{g} / \mathrm{m}^{3}$ in month of march and lowest value observed $118.37 \mu \mathrm{g} / \mathrm{m}^{3}$ in month of December.

The permissible limit for PM10 in annual basis is $60 \mu \mathrm{g} / \mathrm{m}^{3}$. The value of PM10 is above the permissible limit it means air pollution is observed due to PM10 partials.

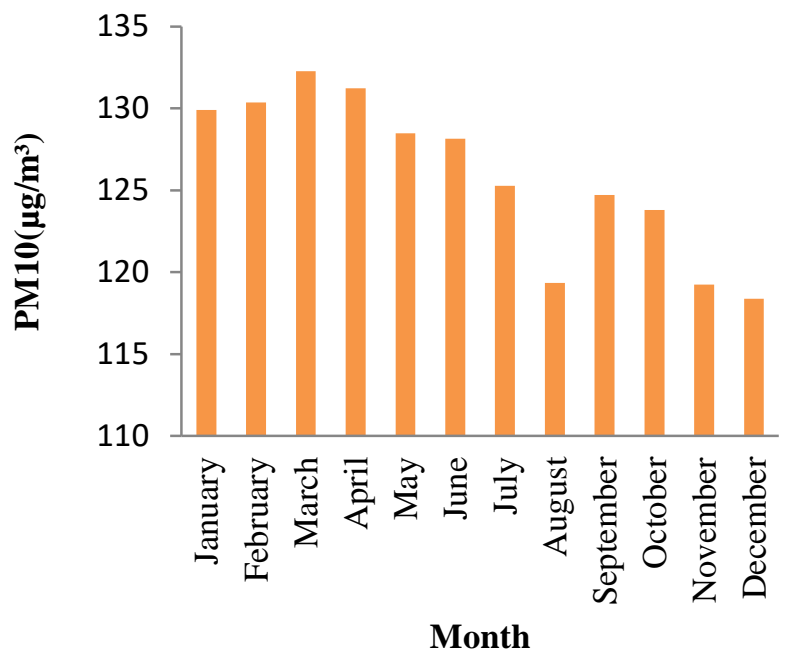

Figure 1 : PM10 values in Haldwani 12 month of 2018

\section{B. SPM}

SPM value lie between 185.37 to $219.3 \mu \mathrm{g} / \mathrm{m}^{3} \mu \mathrm{g} / \mathrm{m}^{3}$. The highest value observed is $219.3 \mu \mathrm{g} / \mathrm{m}^{3}$ in month of march and lowest value observed $185.37 \mu \mathrm{g} / \mathrm{m}^{3}$ in month of december. The permissible limit for SPM in annual basis is $40 \mu \mathrm{g} / \mathrm{m}^{3}$. The value of SPM is above the permissible limit it means air pollution is observed due to SPM partials.

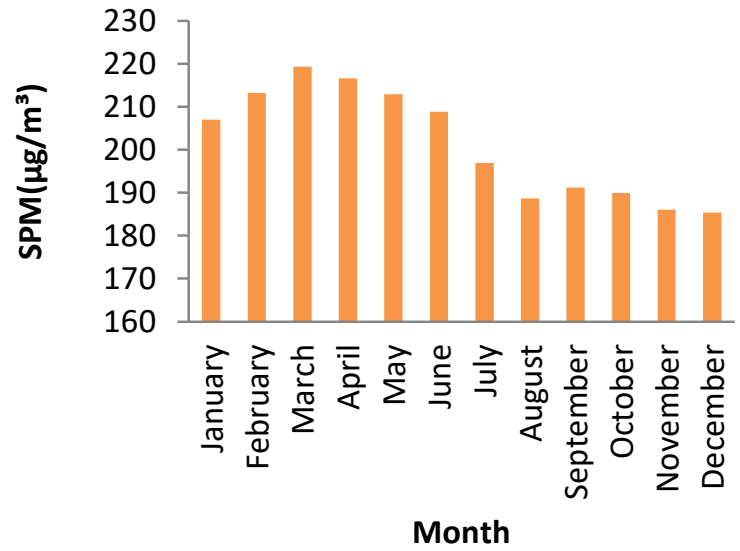

Figure 2: SPM values in Haldwani 12 month of 2018

\section{C. $\mathrm{SO}_{2}$}

$\mathrm{SO}_{2}$ value lie between to $8.65 \mu \mathrm{g} / \mathrm{m}^{3}$ to $12.3 \mu \mathrm{g} / \mathrm{m}^{3}$. The highest value observed is $12.3 \mu \mathrm{g} / \mathrm{m}^{3}$ in month of november and lowest value observed $8.65 \mu \mathrm{g} / \mathrm{m}^{3}$ in month of december. The permissible limit for $\mathrm{SO}_{2}$ in annual basis is $50 \mu \mathrm{g} / \mathrm{m}^{3}$. The value of $\mathrm{SO}_{2}$ is within permissible limit it means air pollution is not observed due to $\mathrm{SO}_{2}$ partials.

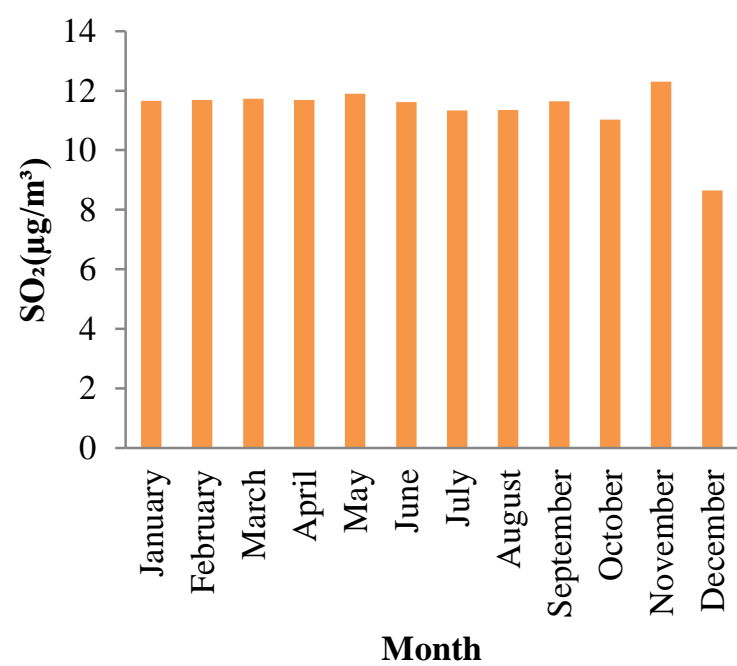

Figure 3: $\mathrm{SO}_{2}$ values in Haldwani 12 month of 2018

\section{D. $\mathrm{NO}_{2}$}

$\mathrm{NO}_{2}$ value lie between $21.42 \mu \mathrm{g} / \mathrm{m}^{3}$ to $23.79 \mu \mathrm{g} / \mathrm{m}^{3}$. The highest value observed is $23.79 \mu \mathrm{g} / \mathrm{m}^{3}$ in month of january and lowest value observed $21.42 \mu \mathrm{g} / \mathrm{m}^{3}$ in month of october. The permissible limit for $\mathrm{NO}_{2}$ in annual basis is $40 \mu \mathrm{g} / \mathrm{m}^{3}$. The value of $\mathrm{NO}_{2}$ is within permissible limit it means air pollution is not observed due to $\mathrm{NO}_{2}$ partials.

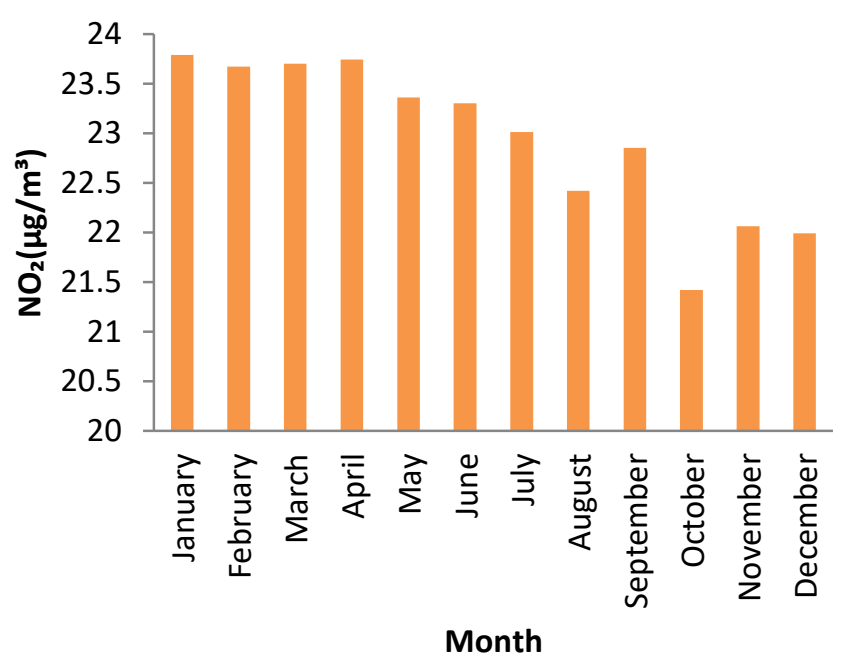

Figure $4: \mathrm{NO}_{2}$ values in Haldwani 12 month of 2018 


\section{CONCLUSION AND FUTURE SCOPE}

According to this study we reached at conclusion that the overall quality of air in Haldwani is in the acceptable limit of CPCB norms but not very good for health of children and elderly peoples. Due to many industrial plants in the city they affect the quality of air in city. We can do study of areas which are affected by air pollution and getting for the solution to reduce it.

\section{REFERENCES}

[1] Agarwal M., Singh S.K., Singh, J. and Rao D.N. (1991) "Biomonitoring of air pollution around urban and industrial sites," Journal of Environmental Biology, vol. 12,pp211-222.

[2] Chauhan Avnish, Pawar Mayank, Kumar Rajeev and Joshi P. C. "Ambient Air Quality Status in Uttarakhand (India): A Case Study of Haridwar And Dehradun Using Air Quality Index," Journal of American Science, vol. 6(9),pp565-568

[3] Chauhan A. and Joshi P.C.(2008) "Air quality index and its variations in Haridwar," Journal of Environment and Bioscience, vol. 22 (2), pp171-176.

[4] Joshi P.C., Swami A. and Gangwar K.K. (2006) "Air quality monitoring at two selected traffic junctions in the city of Haridwar," Himalayan Journal of Environmental and Zoology, vol. 20(2), pp219-221.

[5] Chelani A.B. and Devotta S. (2007) "Air quality assessment in Delhi: Before and after CNG as fuel," Environmental Monitoring and Assessment, Volume 125, Issue 1-3, pp 257-263.

[6] CPCB (2001). National ambient air quality statistics of India. Central Pollution Control Board, Parivesh Bhavan, Delhi, India

[7] Rao D.N. and F. Leblanc (1966) "Effects of SO2 on the lichens alga with special reference to chlorophyll," The Bryologist, Vol. 69, No. 1 pp. 69-75.

[8] Chauhan Avnish (2010) "Photosynthetic pigment changes in some selected trees induced by automobile exhaust in Dehradun, Uttarakhand," New York Science Journal 2010,3(2) pp. 45-51.

[9] https://cpcb.nic.in/uploads/National Ambient Air Quality Standards .pdf

\section{AUTHORS PROFILE}

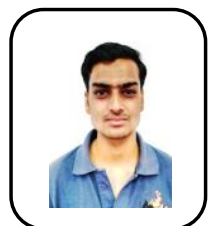

Muchkund Pant is presently student of M.tech Environmental Engineering. Under the department of Civil Engineering Uttaranchal University Dehradun.

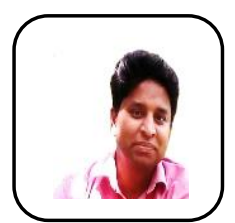

Mr. Awadhesh Chandramauli is presently working as Assistant Professor Department of Civil Engineering, Uttaranchal University Dehradun. $\mathrm{He}$ has published numerous papers in Conferences and Journals. 